\title{
ETNO-NACIONÁLNÍ EMANCIPACE SANDŽACKÝCH MUSLIMŮ V POZDNĚ OSMANSKÉM A JUGOSLÁVSKÉM OBDOBÍ
}

\author{
DANIEL HELER
}

FAKULTA SOCIÁLNÍCH VĚD UNIVERZITY KARLOVY

\begin{abstract}
The Ethno-National Emancipation of the Sandžak Muslims in the Late Ottoman and Yugoslav Periods
\end{abstract}

The Sandžak, or Sanjak of Novi Pazar, is a strategically important region situated between modernday Serbia, Montenegro, Bosnia, and Kosovo. It is well known for its great cultural, religious, and ethnic diversity. As such, the area represents an interesting field for research of inter-ethnic and interconfessional relations. The article traces the ethno-national emancipation of the local Slavic Muslim community since the early nineteenth century until the late 1980s and its confrontation with the nationalisms and expansionisms of the nascent Christian nations and states in the Balkans. It argues that the identity of the Sandžak Muslims transformed from a predominantly religious identity to a national one no earlier than during the socialist modernization in Yugoslavia in the post-WWII period. Keywords: Sandžak; Bosniaks; Muslims; nation-building; Ottoman Empire; Yugoslavia DOI: $10.14712 / 23363231.2017 .1$

\section{Úvod}

Novopazarský sandžak je historický region západu Balkánu se smíšenou muslimsko-pravoslavnou populací, jehož území je dnes od severu na jih rozděleno hranicí znovu nezávislé Černé Hory a Srbska. Z celkové rozlohy zhruba $8400 \mathrm{~km}^{2}$ zabírá východní část Sandžaku, situovaná na jihozápadě dnešního Srbska (okresy Novi Pazar, Tutin, Sjenica, Nova Varoš, Prijepolje a Priboj),

Daniel Heler je doktorand na Institutu mezinárodních studií FSV UK. Korespondenční adresa: Fakulta sociálních věd UK, U Kř́íže 8, 15800 Praha 5. E-mail: daniel.heler@fsv.cuni.cz. 
území $4500 \mathrm{~km}^{2}$. Západní část, ležící na severovýchodě Černé Hory (okresy Bijelo Polje, Pljevlja, Rožaje, Berane - dříve Ivangrad, Plav a Gusinje), se rozkládá na ploše $3900 \mathrm{~km}^{2}{ }^{1}$ Kulturním a hospodářským centrem Sandžaku, historicky spojeným s Bosnou, ale také se srbskou středověkou feudální státností Rašky, je jediné větší sídlo v oblasti - město Novi Pazar.

Sandžak, v osmanské turečtině výraz sançak znamená „prapor“ či „bojová zástava“, se ve druhé polovině 19. století stal nejsevernější výspou, pomyslným posledním praporem ustupující Osmanské říše na Balkánském poloostrově. Pro své strategické umístění byl region, který se rozkládá na prostoru mezi Srbskem, Bosnou a Hercegovinou, Černou Horou a Kosovem, tedy na spojnici Jadranu s Černomořím a střední Evropy s oblastí Egejského moře, mnohokrát objektem zájmu rodících se balkánských národních států i eurasijských mocností.

Novopazarský sandžak, tak jako i jiné balkánské regiony, prošel od konce 19. století řadou nesmírně dynamických procesů formujících kvalitativně zcela jinou, moderní sociální realitu. Postupně gradující úpadek tradičního mocenského hegemona jihovýchodní Evropy Osmanské říše, datovaný nejpozději od druhého obléhání Vídně v roce 1683, nárůst anarchie v dříve př́ísně centralizované říši spojený s relativním úpadkem vojenské moci státu a zaostalost timarsko-sipáhijského feudálního systému, respektive neschopnost radikální socioekonomické reformy, to je jen ve zkratce situace, ve které se nacházely balkánské državy Osmanů na počátku dějinného příběhu Sandžaku jako specifického historicko-geografického útvaru. ${ }^{2}$

Osmanská říše, tedy její privilegované třídy převážně islámské víry, se tak již na počátku 19. století stává z aktivního činitele velmocenské politiky nejen objektem působení imperialismu evropských velmocí, ale i vnitřního separatismu „Turkům“ doposud podřízených skupin obyvatelstva. Snaha křestanské ráje ${ }^{3}$ o defeudalizaci ekonomických a sociálních poměrů a na ni navazující dynamické procesy etno-nacionální mobilizace postupně změní samotný Novopazarský sandžak z regionu dvou konfesí v region dvou národů.

1 Esad Džudžević, Bošnjački identitet (Tutin: CDS, 2012), 15-17. Hranice Sandžaku se samozřejmě v čase měnily. V době pozdní osmanské vlády byla kupříkladu součástí Novopazarského sandžaku i Kosovska Mitrovica se širším okolím, tedy dnešní severní Kosovo. Tento článek nicméně primárně vychází ze současné geografické definice regionu.

2 Oblast dnešního Sandžaku se stala součástí bosenského sandžaku, později pašalíku v polovině 15. století. Viz Muhedin Fijuljanin, Sandžački Bošnjaci (Tutin: CBS, 2010), 11.

3 Rája, z turečtiny, resp. arabštiny, se používá jako označení pro nemuslimské a v osmanském nábožensko-správním systému milétů neprivilegované poddané Osmanské říše. Výraz má individuální i kolektivní význam - poddaný či sprostý lid. 
Tato práce si na základě analýzy nacionálního muslimského/bosňáckého historiografického či historizujícího diskurzu klade za cíl zpracovat v české odborné diskuzi doposud chybějící kritický přehled moderních dějin Sandžaku v rámci širšího regionálního vývoje a především v kontextu etno-nacionální geneze sandžackých slovanských muslimů, Muslimů či Bosňáků. ${ }^{4} \mathrm{~V}$ tomto smyslu se jako relevantní pro výzkum jeví období od počátku 19. století, kdy se začaly vytvářet podmínky pro národnostní uvědomění místních slovanských muslimů - Sandžaklijů, až po afirmaci jejich národnostní identity v rámci socialistické Jugoslávie pod etnonymem Muslimové v sedmdesátých a osmdesátých letech 20 . století. ${ }^{5}$ Konkrétně se autor pokusí odpovědět na následující výzkumné otázky: Jak se utvářela muslimská nacionální identita v podmínkách periferního území Sandžaku? Jaké je možné vysledovat korelace mezi státoprávními či politickými změnami v širším regionu a rozvojem národní identity muslimské komunity Sandžaku? Jaký byl vztah tamější muslimské menšiny ke státu, režimu a státnímu národu, ve kterém, respektive se kterým žila?

Moderní dějiny Sandžaku jako specifického balkánského regionu, zejména téma etno-nacionální geneze místních muslimů, zůstávají poněkud stranou akademického zájmu. Zahraniční badatelé sice věnují velkou pozornost Bosně, Srbsku, Kosovu i Černé Hoře, avšak o prostoru ležícím mezi nimi se zmiňují zpravidla jen letmo. Jedinou výjimkou je nepř́liš̌ kvalitní a nijak rozsáhlá monografie Kennetha Morrisona a Elizabeth Robertsové The Sandžak: A History. ${ }^{6}$ Naopak i vzhledem k politickým kontroverzím okolo regionu a vlastního bosňáckého národa v průběhu rozpadu Jugoslávie - se moderním dějinám Sandžaku i Sandžaklijů intenzivně a často $\mathrm{z}$ vyhraněných nacionalistických pozic věnují místní bosňáčtí či muslimští badatelé jako Safet Bandžović, Esad Džudžević, Muhedin

4 Muslimové (psáno s velkým počátečním písmenem) či dříve muslimové je označení pro národ, který se dnes identifikuje primárně jako Bosňáci. Zatímco termín muslimové, resp. Muslimové upřednostňovaný $\mathrm{v}$ době socialistické Jugoslávie, má zřejmé konfesní konotace, termín Bosňáci, preferovaný v současnosti v Bosně a Hercegovině, v ostatních nástupnických státech socialistické Jugoslávie i mezinárodně, má zřetelné konotace zemské. Sandžaklijové je pojem, který označuje příslušníky muslimské komunity Sandžaku zejména slovanského původu, přičemž tento výraz může někdy nabývat i negativních konotací. Tato práce jej však užívá bez jakéhokoli zabarvení právě jen jako označení slovanských muslimů Sandžaku.

5 Klíčovým obdobím pro afirmaci muslimské nacionální identity (nejen) v Sandžaku, symbolizované změnou etnonyma z Muslimové na Bosňáci, se jeví doba rozpadu socialistické a svazové Jugoslávie, tedy vývoj zhruba od osmdesátých let 20. století do první dekády nového tisíciletí. Vzhledem k omezenému rozsahu tohoto časopiseckého př́íspěvku budou výsledky autorova výzkumu soudobých dějin Sandžaku publikovány v samostatné studii.

6 Kenneth Morrison a Elizabeth Roberts, The Sandžak: A History (London: Hurst, 2013). Více o této knize viz Daniel Heler, recenze knihy, která bude otištěna v následujícím čísle $A U C$ Studia Territorialia. 
Fijuljanin, Raif Hajdarpašić, Mustafa Imamović, Ejub Mušović nebo Šerbo Rastoder. Kritická interpretace těchto zdrojů, tedy zpravidla nacionálních historiografických či historizujících narativů, tvoří základ tohoto časopiseckého př́íspěvku. Uvedené historiografické práce jsou doplněny zdroji primárními, zejména jugoslávskými cenzy a ústavními dokumenty. Pro přiblížení širšího kontextu historického vývoje jihoslovanského prostoru a Balkánu obecně se práce drží zavedených českých a západních publikací.

\section{Osmanský Sandžak a muslimská otázka v době počínající modernity}

Jak již bylo zmíněno, muslimové tvořili v nábožensko-třídním smyslu základ privilegované skupiny či skupin obyvatel Osmanské říše. Slovanští muslimové byli na Balkáně označováni křestanskou rájou za „Turky“ či „poturčence“ nikoli pouze proto, že byli spolu s ostatními muslimy držiteli moci a privilegií, ale i kvůli své vlastní konstrukci identity spojované s Osmanskou říší a světem islámu. Důvody pro konverzi po̊vodně křestanského obyvatelstva k islámu se lišily v čase a místě. Křestané konvertovali k islámu, aby uchránili svůj majetek, staletá privilegia či aby umožnili sociální a materiální vzestup sobě samým a svým potomkům. Islamizace se často netýkala jen jednotlivců, ale celých skupin obyvatelstva, vesnic či rodových společenstev.

Již od časů obležení Vídně v roce 1683 se tito „Turci“v reakci na habsburské výboje, které v 17. a 18. století epizodně zasahovaly i na území Novopazarského sandžaku, počali stahovat na jih Balkánského poloostrova blíže k Istanbulu, přičemž tento proces dále akceleroval v souvislosti se vznikem autonomních a posléze nezávislých křestanských států. Naopak křestané donucení k odchodu z osmanských držav nacházeli útočišsě zejména v habsburské monarchii či Ruské říši, později pak ve „svých“ nově vzniklých národních státech.

Muslimové čítali na počátku prvního srbského povstání (1804-1813)7 jen v bělehradském pašalíku okolo 20000 osob, přičemž koncentrováni byli především v městských typech osídlení. Dne 8. října 1807 dobyli srbští vzbouřenci Bělehrad a „vyčistili“ město od jeho tureckých obyvatel, respektive „poturčencü“ a s nimi dále i židů a řeckých fanariotů. ${ }^{8}$ Mezi notábly i obyčejnými muslimy

7 Přestože povstání $\mathrm{v}$ bělehradském pašalíku hrálo mimořádně významnou roli při utváření moderního srbského národa a obecněji sociální modernizace regionu podle trendů přicházejících zejména ze západní a střední Evropy, samotné povstání nebylo nacionalismem primárně inspirováno. Události původně započaly jako odpor pravoslavných poddaných vůči místním muslimským feudálním vládcům.

8 Mustafa Imamović, Historija Bošnjaka (Novi Pazar: CBS, 2007), 328-29. 
v Sandžaku a Bosně vzbudilo první srbské povstání obecně vážné obavy, a jejich vojska proto již od počátku bojovala proti povstalcům a byla mezi prvními, kdo roku 1813 po porážce povstání vstoupili do „osvobozeného“ Bělehradu. ${ }^{9}$

Povstání se přirozeně přelilo i mezi pravoslavnou ráju v okolí Nového Pazaru, turecky Jeni Bazar, kde „janičáři“ - vazalové na Cařihradu de facto nezávislého paši Pazvantoglu - vykořistovali poddané obyvatelstvo podobně jako jejich protějšky v bělehradském pašalíku. ${ }^{10} \mathrm{~V}$ oblasti epizodně operovalo i Karadjordjevićovo vojsko. To usilovalo o ovládnutí prostoru Sandžaku tak, aby umožnilo spojení s Černou Horou a zároveň narušilo komunikace vedoucí z jihu Balkánu do Bosny. Nikoli naposledy se tím ukázala strategická důležitost Sandžaku jako pomyslného „středobodu“ spojujícího sever s jihem a východ se západem poloostrova. Povstalci mimo jiné v městečku Sjenici vyvraždili podle bosňáckých údajů až několik tisíc muslimů, což dále zjitřilo zdejší již tak komplikovanou interkonfesní situaci. ${ }^{11}$ Válka ostatně uvedla obyvatelstvo $\mathrm{v}$ regionu do pohybu, následkem čehož vzrostl podíl muslimů na celkové populaci Sandžaku. Povstání však bylo i zde po lítých bojích nakonec osmanskou mocí pacifikováno, a to zejména za přispění místních muslimů. ${ }^{12}$

Série revolt dala vzniknout srbskému knížectví s vlastními, rychle se etablujícími elitami přirozeně usilujícími o legitimitu nových pořádků. V souladu s celoevropskými trendy se raison d'être nově se utvářejícího srbského státu staly myšlenky nacionalismu. Krom povstaleckého étosu, pravoslavné víry a vědomí společných socioekonomických zájmů ráji hrálo v procesu utváření novodobého srbského nacionalismu a státu významnou úlohu také „znovuobjevované“ dědictví srbské středověké státnosti.

Bělehradský pašalík, ač postupně územně expandující, však ovládal pouze malou část zemí osídlených pravoslavnými Jihoslovany, přičemž vztah k rodícímu se chorvatskému nacionalismu či širším jihoslovanským idejím zůstával ještě dlouho neujasněn. ${ }^{13}$ Černá Hora v době prvního srbského povstání, a ještě dlouho poté, představovala spíše klanový svaz usilující v podmínkách nehostinných hor o vymanění ze sevření okolní osmanskou mocí než moderní národní stát. ${ }^{14}$ Ostatně otázka identity obyvatel Černé Hory především ve vztahu k srbství

9 Ibid.

${ }^{10}$ Dragi Maliković, „Novi Pazar u Prvom Srpskom Ustanku“, Novopazarski zbornik (1995), 109-13.

11 Fijuljanin, Sandžački Bošnjaci, 76-77.

12 Esad Džudžević, Sandžak: Multietnička regija (Tutin: CBS, 2010), 24-25; Fijuljanin, Sandžački Bošnjaci, 77.

${ }^{13}$ Leften Stavrianos, The Balkans since 1453 (New York: Holt, Rinehart \& Winston, 1958), 231-41.

${ }^{14}$ František Šístek, Černá Hora (Praha: Libri, 2007), 7-9. 
zůstává, alespoň částečně, otevřena až do dnešních dní. Demografické a sociokulturní centrum potenciálního muslimského či bosňáckého národa se přitom nalézalo mezi právě vznikajícími křestanskými národy západu Balkánu, zejména Srby a Chorvaty. 15

Vyhánění muslimů ze „srbských zemí“ se jako masový fenomén znovu objevilo s druhým srbským povstáním v roce 1815. Jedním z důsledků ustavení srbské (polo)autonomie $\mathrm{v}$ bělehradském pašalíku bylo i sestěhování muslimské populace do pouhých šesti pevnostních sídel hájených osmanskou posádkou. Roku 1830 bylo úmluvou autonomních orgánů s Portou, uzavřenou na nátlak Ruska a vyhlášenou sultánovým výnosem, tzv. hatišerifem, rozhodnuto o vystěhování všech muslimů z bělehradského pašalíku. Dne 24 . března 1867 pak předal poslední vojenský velitel Bělehradu klíče od bělehradské pevnosti Kalemegdanu srbskému knížeti Mihailu Obrenovići, a osmanská vojska tak definitivně vyklidila svoje pozice v mladém a malém Srbsku. ${ }^{16}$

Pokud bychom chtěli na př́kladu některého místa ilustrovat etno-konfesní změny, které se v Srbsku udály během několika málo desítek let od prvního srbského povstání, sotva bychom krom Bělehradu našli výstižnější prŕíklad než Užice. Město ležící v dnešním západním Srbsku poblíž Sandžaku, kde ještě ve čtyřicátých letech 19. století bylo podle bosňáckého historika Mustafy Imamoviće více než 2000 muslimských domů, 20 mešit a pouze 80 křestanských usedlostí, bylo svými tehdejšími obyvateli nazýváno malým Cařihradem. ${ }^{17}$ Doba se změnila a dnes nestojí v Užici mešita žádná a muslimové zde téměř nežijí, což bylo a je zejména v nedalekém Sandžaku vnímáno dodnes velmi citlivě.

Také samotná Bosna, a Novopazarský sandžak jako její tehdejší součást, se v průběhu 19. století pozvolna stávala místem emancipace, soupeření, či naopak konverze srbského a chorvatského nacionalismu. Jak Chorvaté, tak Srbové spolu se stoupenci jihoslovanské jednoty považovali Bosnu z historického a etnického pohledu za přirozeně svoji, na což samozřejmě senzitivně reagovali místní

15 Podobně jako slovanští muslimové zůstaly nacionalismem prakticky netknuty až do konce 19. století i etnicky turecké komunity žijící na území celého osmanského impéria a osmanské elity. Turecký nacionalismus se v zásadě datuje od tzv. mladoturecké revoluce a masově se širril až v souvislosti s odporem proti okupaci mocnostmi a Řeckem po první světové válce. Vítězství ve válce proti Recku, stažení mocností z Malé Asie a vytvoření sekulární Turecké republiky znamenalo náhlý konec nadnárodního impéria založeného na předmoderním třídněreligiózním pořádku. Turecko se poté etablovalo jako moderní stát založený na tureckém nacionalismu bez mocenských či dokonce územních aspirací vůči zbylým osmanským elementům na Balkáně. Viz Imamović, Historija Bošnjaka, 521-22.

16 Ibid., 329-31.

17 Ibid. 
muslimové. Jak uvádí Ladislav Hladký, „nebezpečí válek a vpádu křestanských vojsk nebývale sjednotilo muslimskou komunitu v Bosně bez rozdílu - begy [příslušníky muslimské aristokracie - pozn. aut.] i prosté muslimské sedláky. Bosenští muslimové napevno spojili svůj osud s osudem Osmanské řriše a Bosenského pašalíku. Osmanskou říši považovali za garanta své víry a svobody. $V$ důsledku toho patřili také bosenští muslimové k nejhorlivějším obráncům islámu. [...] Konfesijní spory v Bosně se ještě více prohloubily. Zdejší společnost se rozdělila na dva tábory, muslimy a křestany, z nichž každý zastával jiné politické zájmy."18

Vypjatý třídně-religiózní konzervativismus typický pro muslimskou bosenskou nobilitu a odmítání jakýchkoli reforem přicházejících z Cařihradu ústící až ve snahu o získání autonomie Bosny, která je v bosenském nacionálním narativu personalizována v postavě Huseina bega Gradaščeviće, se samozřejmě projevovaly i v Novopazarském sandžaku. ${ }^{19}$ Zdejší muslimové v této době sami sebe stále pokládali především za součást univerzalistické islámské komunity v rámci Osmanské říše. Slovanští muslimové na Balkáně obecně byli moderními křestanskými nacionalisty považováni většinou za pouhé „odrodilé poturčence“, př́ičemž, jak už bylo zmíněno, jejich vlastní identita nebyla zatím nacionalismem prímo ovlivněna. ${ }^{20}$

Na konci šedesátých let 19. století byla v Bosně provedena poslední osmanská správní reforma, která vytvořila Bosenský vilájet (či lépe řečeno potvrdila Bosnu jako vyšší správní jednotku), do něhož byl jako nižší správní jednotka začleněn i Novopazarský sandžak. Reforma, navazující na tzv. hatišerif z Gülhany ${ }^{21} \mathrm{z}$ roku 1839 , měla také přinést větší podíl nemuslimů na správě věcí veřejných, respektive zajistit jejich zrovnoprávnění s muslimy tak, jak to předpokládal právě zmíněný hatišerif. $\mathrm{V}$ roce 1875 se však v Hercegovině a Bosně rozhořelo povstání ráji, jež bylo zprvu motivováno zejména její neutěšenou materiální situací způsobenou neúrodou a vysokým zatîžením daněmi a dávkami. Do povstání, které vypuklo jako místní boj podmaněných za plody jejich fyzické práce spíše než za politickou či dokonce nacionální emancipaci, se brzy zapojily

${ }^{18}$ Ladislav Hladký, Bosna a Hercegovina: Historie neštastné země (Brno: Doplněk, 1996), 34-35. To ovšem neznamená, že by muslimská společnost v Bosně, a ostatně i na celém Balkáně, nebyla sama o sobě v této době stratifikována. Naopak rozdíly mezi materiálními a mocenskými zájmy i pojímáním vlastní komunity mezi privilegovanou muslimskou aristokracií, islámskými učenci a podmaněnými rolnickými masami byly zřejmé (nejen) v Sandžaku už tehdy a přetrvávaly prakticky až do doby socialistické modernizace.

19 Džudžević, Sandžak, 26.

${ }^{20}$ Miroslav Šesták et al., Dějiny jihoslovanských zemí(Praha: NLN, 2009), 295-97.

${ }^{21}$ Hatišerif z Gülhany, který mimo jiné formálně zrovnoprávnil postavení muslimů a nemuslimů, je považován za počátek reformně-modernizačního období v Osmanské říši, tzv. tanzimátu. 
evropské velmoci i nové balkánské státy Černá Hora a Srbsko. Výsledkem konfliktu mezi zmíněnými aktéry tzv. velké východní krize, kdy byla Osmanská říše za pomoci carského Ruska poražena svými vazalskými státy, bylo ustavení rakousko-uherského protektorátu nad Bosnou a Hercegovinou. ${ }^{22}$ Sandžak však byl ještě v roce 1877, zřejmě v reakci na evidentní destabilizaci Bosny a Hercegoviny, vyčleněn Portou z Bosenského vilájetu a spolu s Prizrenským sandžakem utvořil Kosovský vilájet. ${ }^{23}$

Zahraniční politika Vídně vedená hrabětem Andrássym chtěla zřejmě původně plánovaným obsazením Sandžaku zabránit tomu, aby se Srbsko a Černá Hora s podporou Ruska spojily v jeden stát. Houževnatý ozbrojený odpor místního obyvatelstva (jak „poturčencư“, tak pravoslavných), který byl těsně spojen s odbojem ve vlastní Bosně a Hercegovině i s podporou Bělehradu, Cetinje i Cařihradu, a zájem krizi dále neeskalovat vedly Vídeň k uzavření kompromisní tzv. cařihradské či také novopazarské konvence z 21 . dubna $1879 .{ }^{24}$ Článek 25 závěrečného protokolu Berlínského kongresu tak sice původně předpokládal jakési kondominium, tedy že si Osmanská říše podrží Sandžak a bude zde i nadále vykonávat správu, zatímco podunajská monarchie se zde stane garantem „nových politických pořádků a také svobody a bezpečnosti komunikací“, zmiňovanou konvencí došlo ale $\mathrm{k}$ jeho podstatné modifikaci. ${ }^{25}$ Vídeň sice získala právo držet na území Sandžaku svoje garnizony ve třech sídlech (šlo o Priboj, Prijepolje a Pljevlju) s úhrnným počtem okolo čtyř až pěti tisíc vojáků, avšak do místních záležitostí se nevměšovala. Stejný počet mužů zde mohla mít dislokována osmanská vojska. Sultán a Vysoká Porta tak v Sandžaku, který se nyní stal nejsevernější balkánskou výspou Osmanské říše, zůstali i nadále suverénem nikoli pouze de iure, jako tomu bylo v př́padě Bosny. ${ }^{26}$ Dále je nutné dodat, že obsazení Bosny a Hercegoviny Rakousko-Uherskem vyvolalo vlnu muslimského vystěhovalectví, jejíž nezanedbatelná část směřovala právě do Sandžaku. ${ }^{27}$

22 Hladký, Bosna a Hercegovina, 37-40.

${ }^{23}$ Džudžević, Sandžak, 29. Součástí Novopazarského sandžaku tehdy byla i oblast dnešního severu Kosova s centrem v Mitrovici. Viz ibid., 24.

${ }^{24}$ Imamović, Historija Bošnjaka, 354-55.

25 „The Treaty of Berlin 1878“, The Tablet, 13, http:/archive.thetablet.co.uk/article/20th-july-1878/11 /the-treaty-of-berlin.

26 Safet Bandžović, Iseljavanje Muslimana iz Sandžaka (Sarajevo: Biblioteka Ključanin, 1991), 10-11; Imamović, Historija Bošnjaka, 355-57; Hladký, Bosna a Hercegovina, 43-44.

27 Džudžević, Sandžak, 32. 


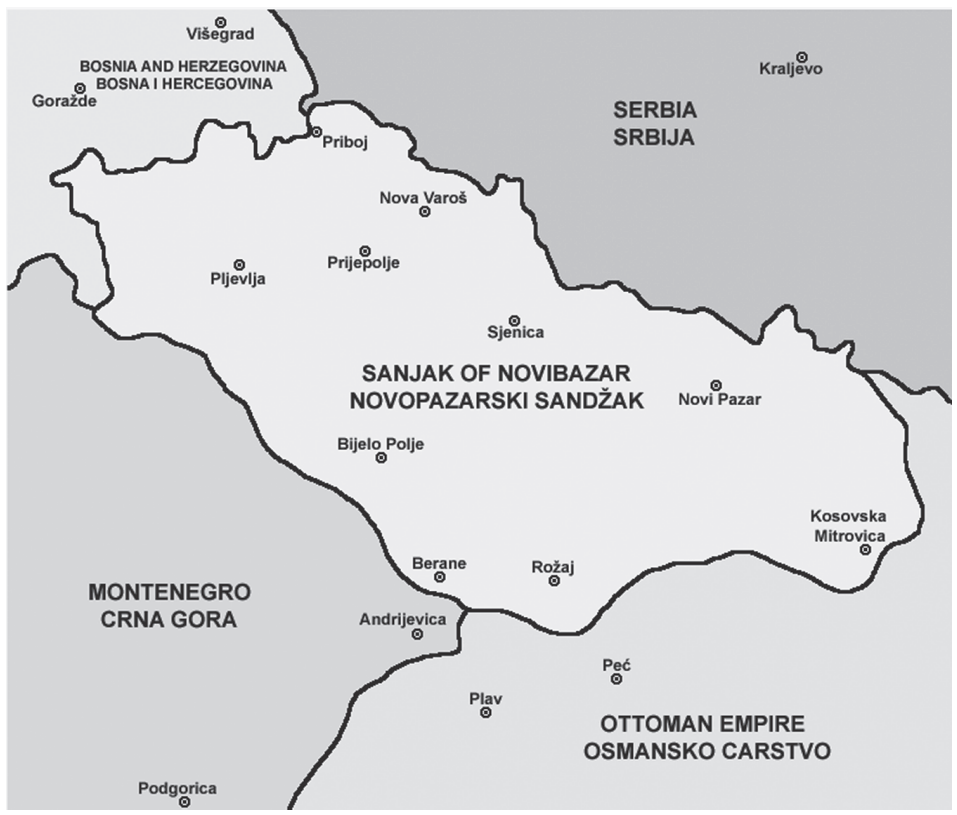

Obr. 1: Novopazarský sandžak v roce 1878 (mapa)

Pozn.: Novopazarský sandžak - kondominium Osmanské říše a Rakouska-Uherska. Srbsko - nezávislý stát. Černá Hora - nezávislý stát. Bosna a Hercegovina - nominálně území Osmanské říše pod okupací Rakouska-Uherska.

Zdroj: Wikipedia, https://commons.wikimedia.org/wiki/File\%3ASanjak_of_Novibazar.png.

Okupace Bosny rakousko-uherskými vojsky měla za cíl nejenom zabránit vzniku jednotného jihoslovanského státu s podporou Petrohradu, ale také vytvořit předpolí pro další expanzi impéria na jih Balkánského poloostrova. ${ }^{28}$ Držba Vojvodiny, Slavonie, Dalmácie, Transylvánie, Bosny a Hercegoviny spolu s vojenskou přítomností v Sandžaku umožňovala Vídni udržovat Srbsko a Černou Horu v de facto polozávislém postavení, tedy ve stavu, kdy se Srbsko nemohlo stát moderním evropským státem..$^{29}$ Sandžak představoval pro všechny zúčastněné, dvě velmoci a dva mladé státy, strategickou křižovatku spojující sever s jihem

${ }^{28}$ Imamović, Historija Bošnjaka, 45-46.

${ }^{29}$ Milan Andrejevich, „The Sandžak: A Perspective of Serb-Muslim Relations“, in Muslim Identity and the Balkan State, eds. Hugh Poulton a Suha Taji-Farouki (London: Hurst \& Company, 1997), 172-73. 
a západ s východem Balkánského poloostrova, Srbsku navíc umožňoval spojení s Jadranem, Rakousku skýtal př́ślib další expanze na jih až do Soluně. ${ }^{30}$

Rozhodnutím Berlínského kongresu byly ustaveny samostatné a také nově územně rozšířené státy Srbsko a Černá Hora. Srbsko získalo oblasti Niše, Pirotu, Toplice a Vranje, odkud odešlo či bylo vyhnáno téměř všechno místní muslimské obyvatelstvo. Černá Hora nově ovládla území Nikšiće, Podgorice, Spuže, Berane, Kolašinu a Baru. To bylo opět provázeno vlnou migrace, kdy z hor přicházeli pravoslavní Černohorci, a muslimové zmíněné oblasti naopak hromadně opouštěli. Muslimští uprchlíci se usazovali hlavně v blízkých provinciích stále ovládaných „nemocným mužem na Bosporu“, výjimkou ale nebylo ani vystěhovalectví do zámoří. V obou nezávislých státech byli zbývající muslimové nezřídka podrobováni nevybíravé asimilaci, která zahrnovala i vynucené konverze „poturčenců“. ${ }^{31} \mathrm{Na}$ druhou stranu je nutné zmínit, že černohorský kníže Nikola se osobně zasazoval o zrovnoprávnění svých muslimských poddaných. Přes všechny praktické problémy byl tudíž černohorský model inkorporace muslimů po roce 1878 výrazně odlišný od toho srbského, směřujícího k co možná největší eliminaci muslimského živlu. ${ }^{32}$ Naopak ze samotného Sandžaku se po Berlínském kongresu vystěhovalo či bylo nuceno vystěhovat větší množství pravoslavného obyvatelstva. ${ }^{33}$

Právě proces vysidlování či naopak zakoušení života minoritního neplnoprávného muslimského obyvatelstva v nových křestanských státech znamenal zásadní impulz a zřejmě i nezbytný předpoklad pro budoucí proces proměny relativně pasivní premoderní muslimské identity v politickou sebeidentifikaci moderní muslimský nacionalismus. Muslimští uprchlíci přicházející do jižních oblastí Osmanské říše, tedy i do Sandžaku, s trpkou zkušeností přirozeně šíríili antagonismus vůči novým křestanským pánům na severu. I v okupované Bosně byla ke konci 19. století již zřejmá konfrontace nacionálně stále nevyhraněných muslimů s pokročilým nacionalismem srbským a chorvatským. Muslimové, kteří byli př́islušníky nově se utvářejících národů zpravidla považováni za poturčené Srby či Chorvaty, tak byli nuceni v konfrontaci s nastupujícím nacionalismem hledat a definovat svoji novou, do budoucna národní identitu. ${ }^{34}$ Muslimské

30 Bandžović, Iseljavanje Muslimana iz Sandžaka, 9.

${ }^{31}$ Imamović, Historija Bošnjaka, 331, 349-50.

32 František Š́stek, Černá Hora (Praha: Libri, 2007), 56-57.

33 Ejup Mušović, „Sandžački Muslimani u etnologii Srbije“, Glasnik Etnografskog instituta SANU 42 (1992): 142.

${ }^{34}$ Safet Bandžović, Iseljavanje Muslimana Crne Gore u Tursku (Podgorica: Matica Muslimanska Crne Gore, 2011), 32; Hladký, Bosna a Hercegovina, 49. Z tohoto období je také známa po dlouhé době první, byt jen epizodně úspěšná, obrana místních muslimů proti nárokům 
prostředí Sandžaku bylo rovněž ovlivňováno vývojem v etnicky albánském prostoru, se kterým se na jihu regionu ostatně do značné míry prolínalo. Albánský, dobovým jazykem řečeno arnautský, element se tak stal významným i v samotném Sandžaku, zejména v oblasti Pešterské náhorní plošiny a v Novém Pazaru, a dodnes tvoří významnou součást multikulturního prostředí v oblasti Plavu.

Je nutné uvést, že v Bosně a samožrejmě i v Sandžaku zůstávalo pozdně osmanské socioekonomické zřízení zakonzervováno až do balkánských válek, respektive až do první světové války. Místní muslimská vojenská aristokracie zpravidla odmítala veškeré pokusy o reformy dosavadního zřízení a emancipaci neprivilegovaných tříd, at už tyto reformy přicházely z Cařihradu nebo z Vídně. Závislost nesvobodných rolníků (tzv. kmetů) na vztazích s držiteli lén (tzv. čiftluků), tedy s muslimskými feudály, zůstala nezměněna a pro křestanskou ráju znamenala $\mathrm{z}$ hlediska materiálního často velmi svízelné postavení. ${ }^{35}$ Jak uvádí Aydin Babuna, v roce 1910 bylo v Bosně muslimského vyznání 91 \% všech vlastníků půdy se závislými nájemci (kmety), dále 70 \% všech vlastníků půdy bez kmetů, 56 \% všech svobodných rolníků a $4 \%$ všech kmetů. Naprostou většinu kmetů představovali obyvatelé pravoslavné víry (73\%) a katolického vyznání (21\%). ${ }^{36}$ Tentýž autor dále dovozuje, že „ve společnosti, kde bylo díky sociální struktuře extrémně obtížné odlišit náboženská práva od ekonomických privilegií, práva vlastníků půdy znamenala muslimská práva a postavení kmetů znamenalo zároveň jejich sociální porobu. $\mathrm{V}$ takovýchto podmínkách nebylo pro muslimské feudály těžké podněcovat náboženské cítění svých souvěrců tak, aby ochránili vlastní materiální zájmy. “37

Samotná oblast Sandžaku se po okupaci Bosny Rakouskem-Uherskem stala nejseverněji položenou periferií Osmanské říše. Osmanská správa zde, stejně jako ve většině ostatních od centra vzdálených provincií, fungovala jen velmi špatně a Sandžak tak zůstal bez dohledu centrálních autorit ve stavu, kdy byl každý v podstatě svým vlastním pánem. Tento stav faktického bezvládí společně

mladých balkánských států a imperialismu velmocí. Dominantně muslimský region Plavu a Gusinje se smíšenou slovansko-albánskou populací byl rozhodnutím Berlínského kongresu přičleněn k Černé Hoře. Kvůli ozbrojenému odporu místních obyvatel muslimské víry, které vedl Ali beg Šabaganić, zvaný Ali paša z Gusinje, však byli Černohorci po několika krvavých střetnutích nuceni od dobývání tohoto regionu upustit. Z oblasti byl vytvořen samostatný osmanský sandžak se sídlem v Plavu a muslimská populace si zde udržela dominanci až dodnes. Černá Hora získala jako kompenzaci pobřežní pás území s rovněž výrazně osmanským městem Ulcinj. Viz Imamović, Historija Bošnjaka, 350-57.

35 Šesták et al., Dějiny jihoslovanských zemí, 295-97; Hladký, Bosna a Hercegovina, 35.

36 Aydin Babuna, „The Bosnian Muslims and Albanians: Islam and Nationalism“, Nationalities Papers 32, č. 2 (červen 2004): 292, doi: 10.1080/0090599042000230250.

37 Ibid. 
s hospodářskými problémy danými periferní polohou a s pozdně feudálním zřízením znamenající pauperizaci značné části obyvatelstva dopadal nejtíživěji na početně převažující chudé bezzemky a malorolníky, tedy zpravidla na pravoslavné obyvatelstvo. ${ }^{38}$ Tím se dále prohlubovaly nábožensko-etnické antagonismy mezi pravoslavnými a muslimy, přičemž pokusy Cařihradu o reformy ve smyslu větší participace nemuslimů na veřejném životě zůstávaly v Sandžaku zpravidla oslyšeny. ${ }^{39}$

V roce 1903 proběhl v Srbském království převrat, který přivedl k moci opět panovníka z dynastie Karadjordjevićů podporovaného radikály. Změna na trůně přinesla i aktivizování velkosrbské politiky země, která společně s Černou Horou jevila zvýšený zájem krom Bosny a Hercegoviny i o tzv. staré srbské země či jižní Srbsko, tedy Makedonii, Kosovo a i Sandžak (Rašku). ${ }^{40}$ V samotném Sandžaku vedly neutěšené sociální podmínky ve stejném roce $\mathrm{k}$ rolnickým bourím a povstání především, ale nikoli výhradně, pravoslavných rolníků proti vysokému daňovému zatížení a celkovému útlaku ze strany dominantně muslimských vládnoucích vrstev. Boje vyvrcholily bitvou u Stožeru, kde osmanské síly pod vedením místního notábla Šemsi paši porazily povstalce, což mělo za následek novou vlnu represí a vystěhovalectví zejména pravoslavného obyvatelstva. ${ }^{41}$

Posledním velkým „dramatem“ před vypuknutím balkánských válek byla tzv. bosenská krize. V roce 1908 Rakousko-Uhersko formálně anektovalo území Bosny a Hercegoviny, které již třicet let ovládalo a na něž po mladoturecké revoluci opět vznášela nárok Osmanská říše. Součástí diplomatických ujednání o de facto uznání tohoto kroku Cařihradem, vedených snahou rakouské diplomacie o zmírnění napjaté mezinárodní situace, bylo krom vyplacení „odškodného“ Osmanské řriši i stažení vojsk podunajské monarchie ze Sandžaku a jeho navrácení pod plnou kontrolu Porty, byt již jen na několik málo let. ${ }^{42}$

Avšak „mimo“ tato významná historická data nadále, a to se zvyšující se intenzitou, probíhaly v regionu procesy reformování dosavadní společenské reality, především formování moderních národů. Novotám, které přinášela mladoturecká revoluce, se v Sandžaku dostalo rozpačitého přijetí jak ze strany muslimských feudálů, kteří se obávali ztráty svých tradičních privilegií, tak

${ }^{38}$ Hospodářské problémy v regionu se zřejmě projevovaly také na životě nižších vrstev muslimské společnosti, do kterých patřili řemeslníci, kupci apod.

39 Bandžović, Iseljavanje Muslimana iz Sandžaka, 9-13; Munavera Hadžišehović, Muslimanka u Titovoj Jugoslavii (Tuzla: Bosanska riječ, 2006), 15-16.

${ }^{40}$ Ladislav Hladký, Bosenská otázka v 19. a 20. století (Brno: Masarykova univerzita v Brně, 2005), $106-7$.

${ }^{41}$ Morrison a Roberts, The Sandžak, 76-77.

42 Andrejevich, „The Sandžak: A Perspective“, 172-73; Hladký, Bosna a Hercegovina, 53. 
křestanské ráji, která zřejmě oprávněně nevěřila $\mathrm{v}$ možnost zlepšení vlastního postavení v rámci státního systému a společenského uspořádání Osmanské říše. ${ }^{43}$ V důsledku anexe Bosny a Hercegoviny se v Sandžaku usídlili další muslimští uprchlíci, tzv. muhadžiři, jejichž přítomnost rozhodně nepřispěla ke smíření rozjitřených interkonfesních či interetnických vztahů v nepokojném regionu. ${ }^{4}$

\section{Sandžak jako součást nově nezávislých křest’anských států}

Těsně před novým kolem válek Srbska, Černé Hory a ostatních křestanských států na Balkáně s Osmanskou říśí v letech 1912-1913 již tvořili muslimové dle vyznání sice křehkou, ale přesto většinu populace zbylých držav „evropského Turecka“". 45 Tato většina byla výsledkem dynamických demografických procesů, zejména sérií válek, počínajíc znovudobýváním Uher ze strany Habsburků a končíc výše popsanými konflikty s balkánskými křestanskými státy, které v 19 . století zapříčinily masový exodus muslimů do zbývajících osmanských provincií na jihu Balkánského poloostrova. ${ }^{46}$

Porážka Osmanské říše v první balkánské válce přinesla nové dělení územních zisků mezi sousední křestanské státy. Takto získaná území však zahrnovala zpravidla regiony, které před balkánskými válkami již měly většinově muslimské osídlení. Počet muslimů, nových „občanů“ Srbska, Černé Hory, Bulharska a Řecka byl přitom enormní. Jen v srbském záboru, tzv. starém či jižním Srbsku, se po balkánských válkách ocitlo více než 1200000 muslimů z celkového počtu 2300000 nově přibyvších obyvatel. ${ }^{47}$ Podle všeho již převážně muslimský Sandžak, dobytý v počátcích podzimní kampaně roku 1912, byl spolu s ostatními osmanskými provinciemi rozdělen mezi vítězné státy - Srbsko a Černou Horu které tak významně zvětšily svou předválečnou rozlohu. ${ }^{48}$

Balkánské války samozřejmě znamenaly (nejen) pro místní muslimské obyvatelstvo existenční hrozbu. Avšak vzhledem ke krátkému období do začátku první světové války, $\mathrm{k}$ relativní neorganizovanosti antimuslimské politiky, málo výkonnému byrokratickému aparátu a v důsledku nasazení vojsk primárně proti státním aktérům nebyly plány na eliminaci či konverzi „poturčenců“

\footnotetext{
${ }^{43}$ Morrison a Roberts, The Sandžak, 85-86.

${ }^{44}$ Ibid.

45 Justin McCarthy, Death and exile: The ethnic cleansing of Ottoman Muslims (Princeton: Darwin Press, 1995), 136.

46 Ibid.

47 Ibid., 162.

48 Andrejevich, „The Sandžak: A Perspective“, 173; Šístek, Černá Hora, 64-65.
} 
a pravoslavnou kolonizaci $\mathrm{v}$ nově přičleněných oblastech balkánských států dovedeny do konce. ${ }^{49}$ Přesto bylo do počátku první světové války, dle bosňáckých údajů, nuceno odejít pouze z černohorského záboru Sandžaku, okolo 12000 muslimů. ${ }^{50}$

Porážka Osmanské říše v první balkánské válce znamenala rozdělení Sandžaku mezi vítěznou Černou Horu a Srbsko, kdy oblasti Novi Pazar, Sjenica, Priboj, Prijepolje i Tutin byly připojeny k Srbsku, zatímco Pljevlja, Bijelo Polje, Berane, Rožaje, Plav i Gusinje připadly nezávislé Černé Hoře. Tehdejší hranice mezi Srbskem a Černou Horou, která v Sandžaku v zásadě odpovídala dnešní mezistátní hranici, dále procházela Kosovem, přičemž Černá Hora získala část Metohie i se sídlem patriarchátu v Peći (turecky Ipek). ${ }^{51} \mathrm{~V}$ souvislosti s obsazováním nových území je v bosňáckém historickém narativu často zdůrazňováno chování relativně disciplinovaného srbského vojska a jeho korektní př́istup $\mathrm{k}$ muslimům, zatímco na černohorské straně záboru docházelo k četným násilnostem, nuceným konverzím k pravoslaví, zabíjení, rabování i pálení muslimských usedlostí. ${ }^{52}$ Nejpravděpodobnějším vysvětlením takto kontrastujícího charakteru zabírání Sandžaku Bělehradem a Cetinje je zřejmě obecný rozdíl v disciplinovanosti srbských a černohorských vojsk i v efektivitě fungování státního aparátu.

V jihovýchodní Evropě, kde probíhala světová válka jako v zásadě pokračování válek balkánských, konflikt přinesl, tak jako i jinde, všeobecné strádání, ztráty na lidských životech i materiálních hodnotách. Samotné válečné operace se odehrávaly také v Sandžaku, přičemž do války proti Rakousku-Uhersku zde bylo mobilizováno pravoslavné i muslimské obyvatelstvo. Mobilizace muslimů zapřícinila tenze v armádě, nespokojenost, časté dezerce a následně vytváření tzv. zeleného kádru ${ }^{53}$ či muslimských gerilových oddílů (komitů) bojujících proti novým pořádkům i pro kořist. ${ }^{54}$

${ }^{49}$ McCarthy, Death and exile, 139.

${ }^{50}$ Imamović, Historija Bošnjaka, 456-58.

${ }^{51}$ Ibid., 458.

52 Koncem roku 1913 byly tyto „excesy“ na zásah černohorského krále zastaveny, což zahrnovalo i reverze násilných konverzí, znovuotevření náboženských institucí apod. Příkladem páchaného př́íkoří může být obsazení Plavu a Gusinje, kde nepravidelná černohorská vojska pobila stovky místních muslimů a kde byly vynucovány hromadné konverze ke křestanství. Pop z Gusinje Djordje Šekularac tak pokřtil během několika dní skoro 12000 místních muslimů. Viz Šístek, Černá Hora, 64-65; Raif Hajdarpašić, Sandžak 1912-1929 (Sarajevo: GIK Oko, 2003), 46-47; Fijuljanin, Sandžački Bošnjaci, 95-97.

53 Zelený kádr je termín užívaný pro skupiny armádních zběhů, kteří se často zabývali i loupežnictvím.

54 Oddíly rezistence vznikaly v průběhu války také na srbské a černohorské straně. 
Muslimové byli také později verbováni pro spolupráci s rakouskými okupačními silami, masově proběhla mobilizace do muslimských milicí, tzv. djurumlijí, působících v Sandžaku, ale i na Kavkaze či v Arábii. Muslimové tak byli po válce nejen oficiálními místy vnímáni jako zrádci. ${ }^{55} \mathrm{~K}$ tomu přispěla i sjenická konference z roku 1917, kdy se místní muslimští předáci vyslovili ke statusu Sandžaku, přičemž jednohlasně podpořili spojení bývalé srbské a černohorské části, které byly za války okupovány Rakouskem, s Bosnou a Hercegovinou, anektovanou Vídní v roce 1908. Po válce byli účastníci konference obviňováni z austrofilství a stíháni pro spolupráci s nepřítelem. V současném bosňáckém i srbském nacionálním diskurzu je konference zpravidla interpretována jako jasný doklad toho, jak bosňácký lid Sandžaku chápal svoji národní identitu a státní príslušnost. ${ }^{56}$

Po první světové válce vzniklo $v$ atmosféře stále pocitovaného mezinárodního i domácího napětí Království Srbů, Chorvatů a Slovinců, a to nikoli pouze jako útvar preferovaný vládnoucími kruhy v Bělehradě. Idea jednotného státu byla podpořena také širší jihoslovanskou politickou reprezentací a rovněž mezi lidem nebyla myšlenka sjednocení jihoslovanských zemí nepopulární. Jak se však poměrně záhy začalo ukazovat, teze o jednom národu o třech větvích, ${ }^{57}$ žijícím ve společném státě pod vládou krále z dynastie Karadjordjevićů, byla $\mathrm{z}$ mnoha politických, hospodářských a kulturních důvodů jen fikcí. Kvůli rozdílným pohledům na uspořádání společného státu (spor unitarismus versus federalismus) i vzhledem k socioekonomickým a zahraničněpolitickým problémům se meziválečná Jugoslávie nacházela ve stavu téměř permanentní krize. ${ }^{58}$

Základem této krize byla národnostní otázka, často se ovšem prolínající s otázkou sociální. Jestliže třem titulárním větvím jednoho národa byla přiřazována identita srbská (zahrnující i Černohorce a pozdější Makedonce), chorvatská a slovinská, slovanští muslimové či „poturčenci“ byli považováni jen za př́íslušníky specifické náboženské obce, na které byl zpravidla ze srbské a chorvatské strany vyvíjen nátlak, aby se přriradili k jedné či druhé národnosti. Přijmout srbskou nebo chorvatskou nacionální identitu by však pro muslimy znamenalo zároveň i svým způsobem akceptovat identitu katolickou či pravoslavnou, což bylo pro

\footnotetext{
55 Hajdarpašić, Sandžak 1912-1929, 82-83, 85, 89, 144, 147; Fijuljanin, Sandžački Bošnjaci, 92.

56 Fijuljanin, Sandžački Bošnjaci, 92-94.

57 Teze o třech větvích jugoslávského národa připomíná konstrukci o dvou národních větvích státního národa meziválečného Československa.

${ }^{58}$ Hladký, Bosna a Hercegovina, 62.
} 
velkou většinu muslimů nepřijatelné, a to i odhlédneme-li od toho, že by takováto akceptace představovala logický nonsens. ${ }^{59}$

Otázka nacionální identity slovanských muslimů v meziválečné Jugoslávii však zůstávala otevřena, nebot', jak uvádí Ladislav Hladký, „pro prosté muslimy (a těch byla v meziválečné Jugoslávii stále drtivá většina) byla abstrakce při rozhodování o národnostním zařazení př́liš složitá a popravdě v podstatě bezúčelná. Lidé z venkova zůstávali především ,muslimy‘, př́ípadně se hlásili ke svým regionálním jménům. “60 $\mathrm{Na}$ druhou stranu však již probíhaly procesy politizace muslimského společenství. Meziválečné období je typické zakládáním stran a spolků a nelze nevidět, že v intelektuálních kruzích se začaly objevovat úvahy o jihoslovanských muslimech jako o nikoli jen náboženské a kulturní, ale i národní pospolitosti. ${ }^{61}$

Problematickým se stal vztah jihoslovanských muslimů k bývalé Osmanské říši - nově Turecku, kde se po vítězství nad Řeckem i diktátem mocností začal rychle formovat moderní sekulární národní stát založený na nacionalistickém principu bez aspirací na začlenění ostatních muslimů, nebot byl zrušen univerzalistický sultanát a později i chalífát. Sekularizace a nacionalizace v Turecku však měly spíše jen nepřímý vliv na polarizaci, která postupně probíhala i v Sandžaku. Zdejší muslimská společnost, respektive především její elity se v této době začaly diferencovat na tradicionalisty a modernisty, tendující bud' k neoosmanismu, nebo k modernímu nacionalismu. ${ }^{62}$

V Království SHS bylo muslimské obyvatelstvo, nejen viděno prizmatem bosňácké historické paměti, vystaveno ze strany státu a především nestátních aktérů administrativní šikaně, loupení i vraždění. Tak tomu bylo i v periferním a válečnými událostmi pauperizovaném Sandžaku. Zde se ve vsích Šahovići a Pavino Polje, ležících v bývalé Černé Hoře, odehrál v roce 1924 zřejmě největší pogrom proti muslimskému obyvatelstvu. Pro podezření z vraždy okresního náčelníka Boško Boškoviće bylo pravoslavnými ozbrojenci zabito několik set muslimů včetně žen a dětí, což vyústilo v exodus muslimského obyvatelstva z celého širokého okolí. Tato událost je široce reflektována v současné bosňácké

\footnotetext{
${ }^{59}$ Ibid., 66-67. Postavení neslovanských národnostních menšin především na jihu tzv. starého Srbska bylo ještě o poznání komplikovanější, nebot diskriminace menšin (dle pravidla čím odlišnější tím problematičtější) nebyla v meziválečném období na Balkáně výjimkou, ale spíše pravidlem.

${ }^{60}$ Hladký, Bosna a Hercegovina, 68.

${ }^{61}$ Ibid.

${ }^{62}$ Imamović, Historija Bošnjaka, 521-22.
} 
historiografii, a co víc, obvykle je považována za symptomatickou ve vztahu pravoslavných $\mathrm{k}$ Muslimům/Bosňákům. ${ }^{63}$

Zároveň je nutné si uvědomit, že banditismus, často spojený s interkonfesními a interetnickými problémy, byl v meziválečné době typický pro celou Jugoslávii, tudíž to platí i pro odbojné sandžacké muslimské komity. S tím souvisí i fenomén rozsáhlých rolnických bouří, zejména tam, kde nebyla provedena reforma osmanských feudálních pořádků či ji př́padně narušila Velká válka. Především muslimové vnímali tyto selské bouře nejen jako sociální, ale z logiky věci i jako konfesně-etnické srážky. Jak uvádí Ladislav Hladký, „kmetové vysvětlovali své počínání jako odplatu za staletý útisk ze strany ,Turkůc, jako ,výměnu stráží v novém státě“. ${ }^{64}$

Z počátku 20. století máme také první relevantní údaje o počtu a etno-konfesním složení obyvatelstva Sandžaku. Počet obyvatel regionu se pohyboval $\mathrm{v}$ roce 1911 okolo 170000 , z toho většina, možná až $80 \%$, byla muslimského vyznání. ${ }^{65}$ Podle výsledků cenzu z roku 1931 však žilo na území bývalého Sandžaku již 276000 obyvatel, z toho polovina muslimů a ostatní pravoslavní. ${ }^{66}$ Často se hovoří o masovém odchodu muslimů od roku 1912, zapříčiněném jak násilnostmi a ztrátou hospodářských a sociálních pozic, respektive touhou po zlepšení materiálního postavení, tak náboženským fanatismem spojeným s agitací náboženských elit a podporou vystěhovalectví ze strany Bělehradu i Istanbulu/Ankary. ${ }^{67}$ Muhedin Fijuljanin uvádí, že do vypuknutí druhé světové války emigrovalo ze Sandžaku až 60000 muslimů. ${ }^{68}$ Reálný počet odešedších byl však zřejmě výrazně nižší, už vzhledem k tomu, že census z roku 1931 napočítal v Sandžaku zhruba stejně muslimů jako ten osmanský z roku 1911. Faktorem, který významně změnil demografický obraz tohoto území, byla spíš než muslimská emigrace zejména kolonizace Sandžaku pravoslavným obyvatelstvem přicházejícím z přelidněných jádrových oblastí Srbska a Černé Hory. ${ }^{69}$ Signifikantní pro přístup Bělehradu k muslimskému obyvatelstvu také slovanského původu byla konvence o vystěhování Turků a „lidí turecké kultury“ z roku 1938, uzavřená mezi Jugoslávií a Tureckem, která předpokládala odchod dalších 40000 rodin

\footnotetext{
63 Ibid., 491-92.

${ }^{64}$ Hladký, Bosna a Hercegovina, 63.

65 Hajdarpašić, Sandžak 1912-1929, 64-65; Andrejevich, „The Sandžak: A Perspective“, 173.

66 „Stanovništvo poveroispovestiimaternjemjeziku po popisu 31.marta 1931.godine“, oficiálnístránka Statistického úřadu Republiky srbské, http://pod2.stat.gov.rs/ObjavljenePublikacije/G1931 /pdf/G19314001.pdf.

${ }^{67}$ Zoran Janjetović, Deca kraljeva, pastorčad kraljeva (Beograd: INIS, 2005), 68-69.

${ }^{68}$ Hajdarpašić, Sandžak 1912-1929, 117.

69 Janjetovič, Deca kraljeva, 246-47.
} 
islámské víry z jihu Jugoslávie, a to za úplatu z její strany. Vzhledem k blíźící válce však nebyla naplněna. ${ }^{70}$

Po dobu více než deseti let probíhala v Království SHS pozemková reforma, která měla zbavit zemi především osmanských feudálních přežitků. Podle posledního osmanského cenzu bylo v Sandžaku pouze necelých $5 \%$ vlastníků půdy nemuslimů. ${ }^{71}$ Zatímco jugoslávskou historiografií, a nutno dodat, že i do té doby v mnoha oblastech Jugoslávie ekonomicky neprivilegovaným především křestanským obyvatelstvem, byla pozemková reforma chápána jako „jednoznačně progresivní akt" odstraňující sociálně nespravedlivé vztahy, reformou postižení především „turečtí“, ale i jiní „cizi“" vlastníci půdy a držitelé feudálních privilegií se ze ztráty svých tradičních výsad samozřejmě netěšili. Agrární reforma, která významně proměnila hospodářské vztahy v Jugoslávii, z logiky věci měla vliv i na další vývoj nejen muslimské společnosti, ale i interetnických vztahů. Potvrzením této teze může být i to, že bosňácká historiografie o celé akci někdy referuje jako o „ekonomické genocidě spáchané na muslimském/bosňáckém národě“. $72 \mathrm{~S}$ otázkou reformy držby půdy v souvislosti s interetnickými vztahy je spojena i problematika vakufů - islámských nadací, jejichž část byla zahrnuta do přerozdělení a zbytek podroben státnímu dozoru. ${ }^{73}$

Právě agrární reforma vedla k politické aktivizaci muslimské begovské vrstvy i měštanstva. Zakládány byly první politické strany jako reprezentantky muslimů v SHS. V Bosně to byla konkrétně Jugoslovenska muslimanska organizacija, která měla přesah i do severních oblastí Sandžaku a jíž bylo z politických důvodů úřady bráněno v činnosti v jižních oblastech země. V „jižním Srbsku“, tedy Sandžaku, Kosovu a Makedonii, se tak hlavním reprezentantem muslimů stala strana $D \check{z} e m i-$ jet, formovaná muslimskými předáky bez rozdílu etnicity a zastupující slovansky, albánsky, turecky, ale především stále ještě osmansky cítící muslimy. Obě tyto strany byly přitom aktivní nejen na lokální a regionální úrovni, ale měly zastoupení i v celostátní skupštině. Zde se za jisté ústupky, nejen v otázce agrární reformy, chovaly $\mathrm{k}$ vládnoucímu režimu v zásadě loajálně. S nástupem královské diktatury byly ovšem roku 1929 úředně zakázány všechny politické strany založené na národnostním či náboženském základě včetně těch, které zastupovaly muslimské obyvatelstvo. ${ }^{74}$ Ve stejném roce se Sandžak v rámci nového správního systému, který měl za cíl nivelizovat dosavadní partikulární historické státoprávní tradice

\footnotetext{
70 Ibid.

${ }^{71}$ Hajdarpašić, Sandžak 1912-1929, 117.

72 Hladký, Bosna a Hercegovina, 64-65.

73 Hajdarpašić, Sandžak 1912-1929, 134.

74 Ibid., 91, 98, 100; Janjetović, Deca careva, 174, 341-42.
} 
jihoslovanských zemí, stal spolu s částí Metohie, s Černou Horou a k ní přilehlými oblastmi Bosny a Hercegoviny součástí Zetské bánoviny se sídlem v Cetinje. Ostatně i v období Království SHS byl Sandžak administrativně oddělen od Bosny a Hercegoviny a navíc rozdělen mezi dvě správní oblasti Užice a Raška.

I po sjednocení rakousko-uherských, srbských a černohorských zemí zůstaly muslimské náboženské komunity z jihu, tedy Srbska a Černé Hory (v čele komunity stál nejvyšší muftí v Bělehradě), a ze severu SHS, tedy Bosny (v čele tzv. reis-l-ulema se sídlem v Sarajevu), administrativně rozděleny. Sjednocení muslimů z Bosny a Hercegoviny s jejich souvěrci na jihu království přišlo až se zákonem o muslimské náboženské komunitě z roku 1930. Tehdy byli všichni muslimové v Jugoslávii podřízeni muftímu v Bělehradě, což vypovídá o silně centralistickém charakteru režimu, nebot muftího sídlo bylo umístěno v hlavním městě, kde už téměř sto let skoro žádní muslimové nežili. Navzdory centralizaci však zůstala v muslimské náboženské obci Jugoslávie zachována jistá dualita. To reflektovala i existence dvou vrchních kolektivních orgánů islámské komunity, tzv. ulema medžlisů, a rad náboženských nadací, tzv. vakufů, v Sarajevu a Skopje. ${ }^{75}$ V Sandžaku bylo sídlo muftího v Novém Pazaru a Pljevlji, přičemž oba muftijáty spadaly pod působnost Skopje. ${ }^{76}$ Co se týče islámského práva, zůstaly v Království SHS zachovány šariatské soudy rozhodující pouze ve věcech rodinných a dědických. ${ }^{77}$ Islámští náboženští činovníci, kteři mimo jiné prováděli i správní úkony jako vedení matrik, se stali státními zaměstnanci spadajícími pod ministerstvo pro náboženské záležitosti. O muslimské komunitě v meziválečné Jugoslávii, kam především v islámských náboženských kruzích pronikalo moderní myšlení jen velmi pozvolna, lze pak obecně hovořit jako o dosti konzervativní. ${ }^{78}$

Co se týče vzdělávání nejen sandžackých muslimů, i v meziválečném období převažoval systém vzdělávání náboženského. V každém větším sídle byly základní náboženské školy (mekteby) pro děti od sedmi let, ve kterých výuka probíhala především v turečtině a arabštině, jazycích (bývalé) správy a náboženství. Základem výuky bylo náboženství spočívající hlavně ve studiu koránu, zastoupeny však byly i světské nauky. Střední vzdělání poskytovaly tzv. medresy, ty ovšem v Sandžaku a jeho okolí fungovaly po válce jen dvě - v Pljevlji a Peći. ${ }^{79} \mathrm{~V}$ roce 1925 byla ve Skopji založena státní Velika medresa Kralja Aleksandra, poskytující

75 Živko M. Andrijašević a Šerbo Rastoder, The History of Montenegro (Podgorica: CICG, 2006), 185.

${ }^{76}$ Imamović, Historija Bošnjaka, 506-9, 517; Hajdarpašić, Sandžak 1912-1929, 173.

77 Andrijašević a Rastoder, The History of Montenegro, 185.

78 Janjetović, Deca kraljeva, 357-58, 360.

79 Hajdarpašić, Sandžak 1912-1929, 109. 
vyšší vzdělání náboženské i světské. Tato instituce, původně zamýšlená jako vzorová pro výchovu nových muslimských elit v duchu loajalismu, se vzápětí poněkud paradoxně stala místem odporu k režimu a dokonce „semeništěm“ komunistických myšlenek. ${ }^{80}$

Hospodářsky zůstával Sandžak i nadále ekonomickou periferií Jugoslávie, a to i v porovnání s prostředím značně chudšího jihu státu. Zdrojem obživy drtivé většiny místních obyvatel, krom úzké vrstvy státních zaměstnanců, bylo stále zemědělství a pastevectví, popřípadě tradiční řemeslná výroba a maloobchod, což mělo své konsekvence v podobě jen velmi pomalu postupující obecné modernizace společnosti. Hlavní komunikace spojující sever s jihem a západ s východem jugoslávského prostoru, respektive Balkánského poloostrova, nyní vedly mimo území Sandžaku a i výstavba modernějších regionálních sítí byla započata až v polovině třicátých let. Ani v oblasti elektrifikace nezaznamenal region v meziválečném období významnějšího pokroku. Elektrická energie byla dostupná jen spotřebitelům ve větších městech, především veřejným institucím. ${ }^{81}$

\section{Sandžak ve druhé světové válce a v poválečné realitě nové Jugoslávie}

Rychlá porážka královské Jugoslávie ve válce s nacistickým Německem a jeho spojenci Itálií, Mad'arskem a Bulharskem byla zapříčiněna krom očividné disproporce mezi válčícími stranami také situací, kdy se na frontě i v zázemí projevilo rozdílné vnímání královské Jugoslávie ze strany jednotlivých národů či etnik. Jugoslávie, okupovaná téměř všemi svými sousedy, se stala typickou zemí antifašistické rezistence, přičemž Národněosvobozeneckému hnutí Jugoslávie AVNOJ se fakticky podařilo otevřít novou frontu v týlu Osy. Zároveň ale byla pro Jugoslávii typická také kolaborace spojená s nacionálními antagonismy a socioekonomickými problémy. Vedle přímé okupace fašistickými státy s pomocí místních kolaborantů došlo na jaře 1941 i k ustavení satelitního státu Osy - Nezávislého státu Chorvatsko (Nezavisna država Hrvatska, NDH) řízenému ustašovskou diktaturou. ${ }^{82}$

Součástí NDH se krom větši části „historických chorvatských zemi“"stalo, alespoň proklamativně, také území Bosny a Hercegoviny. Zejména vzhledem

\footnotetext{
${ }^{80}$ Janjetović, Deca kraljeva, 246-47.

81 Morrison a Roberts, The Sandžak, 100-1.

82 Miroslav Tejchman, Balkán ve válce a v revoluci. 1939-1945 (Praha: Karolinum, 2008), 280-81; Hladký, Bosenská otázka, 186.
} 
k národnostnímu složení NDH, tedy silně početně zastoupenému srbskému elementu, vedli ustašovci vůči místním muslimům až podbízivou politiku, kdy tito byli označováni oficiální propagandou Záhřebu za "výkvět chorvatství“. 83 O samotný Sandžak se kvůli jeho strategické poloze zajímaly jak fašistické mocnosti Německo i Itálie, tak NDH, a dokonce i Albánie - sama protektorát Itálie. Sandžak, kde neprobíhaly během dubnové válečné kampaně v roce 1941 žádné významnější operace, byl záhy rozdělen mezi okupační správu Itálie a Německa zhruba v hranici dnešní Černé Hory a Srbska, přičemž zde byly dislokovány i ustašovské jednotky. ${ }^{84}$

V celé Jugoslávii brzy vypukl konflikt nacionalistů prakticky všech národů, internacionalistických komunistů a okupantů, tedy svého druhu válka všech proti všem. Pro dějiny Sandžaku bylo, krom komunistického odporu, důležité i tzv. četnické hnutí, které vedl Dragoljub Mihailović v duchu srbského nacionalismu, roajalismu a konzervativismu. Ve svém rozkazu četnickým vojvodům „Draža“ roku 1941 píše: „Cíle našich oddílů jsou: 1) Bojovat za svobodu celého národa pod žezlem Jeho veličenstva Krále Petra II. 2) Vytvořit velkou Jugoslávii a v ní etnicky čisté velké Srbsko v hranicích Srbska, Černé Hory, Bosny a Hercegoviny, Sremu, Banátu a Bačky. [...] 4) Vyčistit státní území od všech menšin a nenárodních elementů. 5) Vytvořit bezprostřední společné hranice mezi Srbskem a Černou Horou a také mezi Srbskem a Slovinskem, vyčistit Sandžak od muslimského živlu a Bosnu od muslimského a chorvatského živlu."85

Nutno říci, že četničtí velitelé př́íkaz svého vůdce důsledně plnili a etnické čistky probíhaly v Sandžaku mezi lety 1941 a 1943 až do porážky partyzány u Prenje, kdy bylo četnické hnutí významně oslabeno. ${ }^{86}$ Snahy četniků o ovládnutí a vyčištění prostoru od nesrbských elementů, spojené s vražděním civilistů a masovým exodem obyvatelstva nikoli pouze muslimského vyznání, se staly hlavním impulzem k formování muslimských milicí téměř v celém Sandžaku, které zpravidla spolupracovaly s okupačními armádami. ${ }^{87}$ Množily se i incidenty s komunistickými partyzány, nebot muslimské milice vedené starými begovskými a hodžovskými (náboženskými) elitami se někdy snažily ve spolupráci s okupanty o restauraci některých prvků osmanských feudálních poměrů, především

${ }^{83}$ Hladký, Bosenská otázka, 186-88; Hadžišehović, Muslimanka u Titovoj Jugoslaviji, 70.

${ }^{84}$ Džudžević, Sandžak, 42.

85 Branko Petranović a Momčilo Zečević, Jugoslovenskifederalizam: Ideje, i stvarnost. Tematska zbirka dokumenata, I. (Beograd: Prosveta, 1987), 676-77.

${ }^{86}$ Imamović, Historija Bošnjaka, 537-39.

87 Ž̌ejmě nejznámnějším případem kolaborace muslimů s okupanty se stalo vytvoření divize SS „Handžar“. 
ve vztahu k držbě pưdy, což mělo samozřejmě negativní vliv na soužití s pravoslavným obyvatelstvem. I pokrokovější část muslimů byla zprvu odrazována od bližší spolupráce s partyzány jejich politikou znárodňování a ateismem. To ovšem nevylučovalo spolupráci partyzánů s muslimskými milicemi proti četnikům na bázi ad hoc. Boje mezi místními nacionalisty a komunisty si jen v Sandžaku vyžádaly podle konzervativnějších odhadů tisíce mrtvých na všech stranách. ${ }^{88}$

Nejen v Sandžaku se lidé postupně v průběhu války začali hromadně přidávat na stranu komunistů - jak kvůli tomu, že tito aktivně bojovali proti okupantům, na rozdíl třeba od četnického hnutí zřetelně tendujícího ke kolaboraci, tak hlavně proto, že se ve zjitřené interetnické situaci jevil internacionalistický program komunistů jako „nejpřijatelnější alternativa vzhledem k politice všech domácích šovinistů, jejichž počínání vedlo jen k vzájemnému nepráatelství a zabíjení“. ${ }^{89}$ Navíc v chudé Jugoslávii existovala již od dvacátých let 20. století významná podpora pro radikální komunistický program v oblasti hospodářské a sociální. Komunisté vyzývali ke spolupráci všech národů a etnik Jugoslávie včetně muslimů, což bývá často považováno za znak de facto uznání této skupiny ze strany národněosvobozeneckého hnutí. ${ }^{90}$

V strategicky významném Sandžaku, rozkládajícím se mezi hlavními operačními zónami partyzánů v Černé Hoře, Bosně a západním Srbsku, se již krátce po začátku okupace, respektive po vyhlášení války SSSR Německem zformovalo komunisty vedené antifašistické hnutí odporu a jeho první orgány. V říjnu 1941 byl založen Hlavní štáb národněosvobozeneckého hnutí Sandžaku, posléze i oblastní výbor komunistické strany a konečně v roce 1943 i regionální zákonodárný orgán ZAVNOS (Zemaljsko antifašističko v(ij)eće narodnog oslobodjenja Sandžaka), odštěp AVNOJ. V př́padě Sandžaku byl tedy zpočátku vývoj orgánů antifašistické fronty v zásadě shodný s budoucími republikami a autonomními entitami Jugoslávie. ${ }^{91}$

Po válce (v Sandžaku trvaly hlavní boje do poloviny ledna 1945) byl však dosavadní status Sandžaku i přes odpor některých řadových bojovníkủ a funkcionářu revokován rozhodnutím předsednictva AVNOJ. Regionální orgány byly tudíž rozpuštěny, respektive transformovány do nižších jednotek, a sám Sandžak administrativně rozdělen mezi Černou Horu a Srbsko, nově svazové republiky

\footnotetext{
${ }^{88}$ Džudžević, Sandžak, 42-44; Hadžišehović, Muslimanka u TitovojJugoslaviji, 76.

${ }^{89}$ Hladký, Bosenská otázka, 198-99.

90 Ibid.

${ }^{91}$ Džudžević, Sandžak, 42, 45.
} 
Jugoslávie. ${ }^{92}$ Klíčoví představitelé nového režimu, jmenovitě Edvard Kardelj a Moše Pijade, argumentovali ve prospěch rozpuštění ZAVNOS potažmo administrativního rozdělení Sandžaku tím, že po válce již neexistuje žádný politický, ekonomický a ani etnický, tím méně vojensko-strategický důvod pro zachování autonomního postavení regionu. ${ }^{93}$

Partizánský odboj, ze své ideologické podstaty v otázce národnostní tolerantní hnutí, nepreferoval na rozdíl od předchozích vládnoucích režimů žádné etnikum. Podle hesla o „bratrství a jednotě“ národů Jugoslávie usiloval o budování nové společnosti založené v marxisticko-leninských intencích na třídních, a nikoliv nacionálních základech. Nacionalismus byl vnímán jen jako komplikace $\mathrm{v}$ procesu výstavby nové společnosti, přičemž $\mathrm{k}$ jeho utlumení mělo dojít ustavením federálního modelu státu a zavedením kulturní autonomie menšin. ${ }^{94}$ Oficiální politikou Jugoslávie padesátých a šedesátých let se tak stal národnostní klid spojený s hospodářským a sociálním rozvojem, přičemž proklamované bratstvo i jedinstvo znamenaly na jedné straně nezdưrazňování podílu jednotlivých jugoslávských etnik na válečných zločinech, na straně druhé ale důsledné trestání projevů nacionalismu..$^{95} \mathrm{~V}$ závěru války bylo ovšem $\mathrm{s}$ fašisty a kolaboranty všech možných národností, a to včetně př́slušníků muslimských milicí i četnikủ, nakládáno zpravidla bez milosti.

V rámci dohod Tito-Šubašić z léta a podzimu 1944 byla sice část loajalistické emigrace, respektive královské vlády $\mathrm{v}$ exilu, začleněna do prozatímní vlády tak, aby byla zajištěna mezinárodněprávní legitimita a vytvořeno zdání státoprávní kontinuity Jugoslávie na Západě, avšak „reakce“ již neměla žádné reálné možnosti ke změně společensko-politických poměrů, které se za války vytvořily na osvobozených územích. Orgány nové lidové moci tak mohly celkem nerušeně pokračovat v provádění revolučních změn v socioekonomických, a tedy ze své podstaty politických otázkách, které ostatně započaly již během národněosvobozeneckého boje. ${ }^{96}$ Jugoslávie, jež za války utrpěla velmi vysoké ztráty na lidských životech (konzervativní odhady hovoří o více než milionu mrtvých) i na materiálních hodnotách, se již nehodlala a ani dost dobře nemohla vrátit k meziválečnému politikaření či královské diktatuře. ${ }^{97}$

92 Ibid., 46.

93 Safet Bandžović, Iseljavanje Muslimana Crne Gore u Tursku, sv. II (Podgorica: Matica Muslimanska Crne Gore, 2011), 47-48.

94 Václav Štěpánek, Jugoslávie, Srbsko, Kosovo: Kosovská otázka ve 20. století (Brno: Muni press, 2011), 106-8.

95 Šesták et al., Dějiny jihoslovanských zemí, 533.

96 Tejchman, Balkán ve válce a v revoluci, 655-57.

97 Ibid., 661-65. 
Vzhledem k vývoji fronty ve východní Evropě a úspěchům národněosvobozeneckého hnutí v zemi se Jugoslávie zprvu stala jednoznačnou součástí sovětské sféry vlivu, přičemž konec války přinesl rychlou sovětizaci, jednu z nejprogresivnějších ve východní Evropě. Po roztržce s Moskvou v roce 1948, kdy se Jugoslávie ocitla v mezinárodní izolaci, procesy sovětizace, nyní již bez Sovětského svazu, po přechodnou dobu dále gradovaly, poté se však jugoslávské komunistické elity pustily do budování specifického systému „samosprávného socialismu“.98 Další posun směrem k liberalizaci poměrů přineslo brionské plénum Svazu komunistů Jugoslávie z roku 1966, kdy byl odstraněn doposud mocný ministr vnitra a př́iznivec centralismu Aleksandar Ranković. Brionské plénum ve svých důsledcích znamenalo další modifikaci jugoslávského modelu, mimo jiné také signifikantní decentralizaci federace. ${ }^{99}$

Jihoslovanští muslimové byli sice orgány AVNOJ a komunistické Jugoslávie považováni v politickém smyslu za rovnoprávné, ale otázka jejich svébytnosti v nacionálním smyslu byla režimem v poválečné době ponechána otevřenou. Výrazem implicitního uznání muslimů jako specifického elementu pestré národnostní mozaiky Jugoslávie bylo i ustavení republiky Bosna a Hercegovina, kterou nejen kvưli promíšenosti srbských a chorvatských populací, ale také vzhledem k existenci specifické muslimské identity nebylo možno rozdělit mezi Srbsko a Chorvatsko. ${ }^{100}$ Namísto bezprostřední afirmace etno-konfesní identity muslimů jako národní probíhaly v nové Jugoslávii pozvolný rozvoj a krok za krokem i uznávání identity této stále ještě převážně národnostně nevyhraněné komunity. Jak konstatuje Ladislav Hladký, „z hlediska národnostního uvědomování bosenští muslimové krátce po válce skutečně většinou stále ještě nevěděli ,kým jsou', ale dosti jasně - at už vědomě, či spíše jen instinktivně - dávali najevo, ,kým nechtějí, resp. nemohou být'.“101

V cenzu z roku 1948 se většina slovanských muslimů v Jugoslávii deklarovala jako „nacionálně nezařazení“ (nacionalno neopredeljeni), menšina pak jako Srbové či Chorvaté muslimské víry či Srbové nebo Chorvaté. Ve sčítání provedeném roku 1953 se většina muslimů vyslovila jako „nezařazení Jugoslávci“ (neopredeljeni Jugosloveni). Již v roce 1961, kdy byla zavedena nová kategorie

\footnotetext{
98 V zahraniční politice socialistická Jugoslávie účelově oscilovala mezi Východem a Západem a zároveň si v rámci tzv. Hnutí nezúčastněných budovala mocenské postavení ve Třetím světě.

99 Pavel Hradečný, „Kosovská otázka v letech 1944-1996“, in Historické souvislosti rozpadu Jugoslávie, Miroslav Tejchman, Pavel Hradečný a Miroslav Šesták (Praha: Historický ústav AV ČR, 1996), 142-43.

100 Hladký, Bosenská otázka, 204.

101 Ibid., 214.
} 
sčítání „Muslimové v etnickém smyslu“ (Muslimani u etničkom smislu), ${ }^{102}$ tedy uznání už nikoli pouze konfesní identity, ale i určitých etno-národních rysů, pro tuto kategorii optovala většina slovanských muslimů. ${ }^{103}$

V souvislosti s vnitřními socioekonomickými a politickými změnami v muslimské komunitě, tedy obecnou modernizací, a v důsledku stále patrnějšího nacionalismu v Chorvatsku, Kosovu a ostatních republikách Jugoslávie bylo i mezi Muslimy možno pozorovat konjunkturu zájmu o nacionální otázky znamenající zrèetelný progres v utváření moderního národa. V únoru 1968 tak mohlo v pobrionské atmosféře konstatovat zasedání Ústředního výboru Svazu komunistů Bosny a Hercegoviny, že „praxe z dřivější doby ukázala škodlivost různých pokusů o nátlak na Muslimy, aby se v národnostním ohledu prohlašovali za Srby, př́padně za Chorvaty, nebot se už předtím prokázalo a dnešní politická praxe to potvrzuje, že Muslimové jsou zvláštní národ“. 104

Jak je z výše uvedeného zjevné, nositelem boje za nacionální afirmaci muslimů byli na první pohled poněkud paradoxně prŕslušníci nové poválečné prokomunistické inteligence, často přímí účastníci národněosvobozeneckého boje, mnohdy přesvědčení marxisté a ateisté. ${ }^{105}$ Při sčítání lidu roku 1971 byla zavedena modifikovaná, z nacionálního hlediska progresivnější kategorie „Muslimové ve smyslu národnosti“" (Muslimani u smislu narodnosti) a o deset let později v roce 1981 i kategorie „Muslimové jako národ“ (Muslimani kao narod), kteří byli nejpočetnější národnostní skupinou v Bosně a Hercegovině - v zásadě jakémsi protonárodním státě Muslimů. ${ }^{106}$

${ }^{102} \mathrm{~V}$ tehdejší diskuzi muslimských marxistických intelektuálů byla odmítnuta myšlenka pojmenovat národ Bošnjaci (Bosňáci) z politických a třídních důvodů, nebot' se dle jejich názoru jednalo o feudální přežitek zprofanovaný rakouskou okupací. Navíc tím bylo v Bosně ponecháno místo i dalším dvěma konstitutivním národům. Muslimové si tak nečinili na Bosnu exkluzivní nárok jako na svou státní entitu, jak by to mohlo vypadat v př́padě pojmu Bošnjak. Viz Hladký, Bosenská otázka, 218.

103 Hladký, Bosna a Hercegovina, 101.

104 Ibid., 102-3.

105 Hladký, Bosenská otázka, 214.

106 John B. Allock, Explaining Yugoslavia (New York: Columbia University Press, 2000), 335-36; Hladký, Bosenská otázka, 214-18. Zajímavá v tomto období je rovněž otázka stability či spíše lability nacionální identity slovanských muslimů, a to především ve vztahu k ostatním muslimským komunitám a nenacionální identitě neoosmanské. Př́ikladem často i účelových proměn identity může být obnovená smlouva s Ankarou o přesídlení Turků z Jugoslávie z roku 1953, kdy do Turecka odešlo i nezanedbatelné množství př́islušníků jiných, netureckých islámských komunit, u kterých ještě přežívalo osmanské kulturní povědomí. Viz Vladimir Ortakovski, Malcinstvata na Balkanot (Skopje: 2-ri Avgust S, 1998), 344; Jan Pelikán, „Poznámky k základním trendům vývoje národnostních vztahů v Makedonii v padesátých letech 20. století“, Slovanský přehled 87, č. 4 (2001): 493. 
Zejména v Sarajevu se již od padesátých let rozvíjel kulturní a politický život muslimů podpořený budováním moderní institucionální infrastruktury (univerzity, orientálního ústavu apod.), který se dále zintenzivnil v období liberálních šedesátých let. Dalším potvrzením nacionální svébytnosti slovanských muslimů se stal roku 1969 kongres historiků Jugoslávie v Ochridu, kde byly předneseny četné referáty $\mathrm{k}$ historii, kultuře, architektuře a literatuře Muslimů. ${ }^{107}$

Avšak i po oficiálním uznání ze strany vládnoucího režimu zůstávala představa, že Muslimové tvoří specifický národ, ještě poměrně nevýrazná, a to jak uvnitř početné části muslimské komunity, tak ještě více v celojugoslávském společenském kontextu. Masovou definitivní afirmaci nacionální identity přínesl až později krvavý rozpad socialistické Jugoslávie. U konzervativněji smýšlejících muslimů/Muslimů také často panovaly smíšené pocity vůči samotnému jugoslávskému státu, nebot jejich komunita byla sice součástí jihoslovanské jazykové majority, zároveň však představovala islámskou minoritou v tradičně křestanské společnosti s ateistickým režimem. ${ }^{108}$

V ústavněprávní rovině vyvrcholila afirmace identity jihoslovanské komunity Muslimů přijetím nové jugoslávské ústavy v roce 1974. Nová ústava definovala Jugoslávii jako „samosprávné demokratické společenství dělnické třídy a pracujících všech rovnoprávných národů i národnostíc. ${ }^{109}$ Již předchozími ústavními dodatky z roku 1971, a poté zmíněnou poslední ústavou druhé Jugoslávie z roku 1974 tak byla potvrzena rovnoprávnost národa Muslimů s ostatními konstitutivními - státními - národy Jugoslávie. ${ }^{110}$ Autonomie menších samosprávných celků - okresů (tzv. opštin) dále vytvářela institucionálně příhodné podmínky pro lokální samosprávu Muslimů i mimo území vlastní Bosny a Hercegoviny.

Nová Jugoslávie zejména v poválečném období vedla nejen v Sandžaku boj proti konzervativním strukturám muslimské společnosti, její tradiční nobilitě a především proti náboženským institucím - šariatským soudům, muslimským řádům, mektebům a medresám. Boj proti „přežitkům staré doby“ byl tak intenzivní, že např́íklad od roku 1947 byla po dobu patnácti let v Černé Hoře zakázána činnost veškerých náboženských škol. ${ }^{111}$ Zavedeno bylo sekulární školství, které mělo ideově podpořit nové společenské zřízení. Ve vzdělávání byly zdůrazňová-

107 Imamović, Historija Bošnjaka, 562-66.

108 Andrejevich, „The Sandžak: A Perspective“, 174.

109 „Ustav Socijalističke Federativne Republike Jugoslavije 1974“, Službeni list SFRJ, č. 30 (21. února 1974): 1-2; Budislav Vukas, Etničke manjine i medjunarodni odnosi (Zagreb: Školska knjiga, 1978), 471.

${ }^{110}$ Hladký, Bosenská otázka, 218.

111 Šerbo Rastoder, Bošnjaci/Muslimani Crne Gore: Izmedje prošlosti i sadašnjosti (Bar: Almanach, 2010), 194. 
ny třídně politické aspekty boje s „reakcí. Běžné bylo trestání spolupráce nejen s okupačními armádami, ale i s místními kolaborantskými organizacemi a milicemi, a to jako kolaborace $\mathrm{s}$ nepř́ítelem $\mathrm{v}$ době války. ${ }^{112} \mathrm{~V}$ rámci „rozkulačení“ byla v zemědělství provedena expropriace pozemků nad 20 hektarů, znárodněna půda náboženských nadací, ale i některé drobné provozovny a obytné domy, což opět primárně dopadlo na místní muslimy. ${ }^{113}$ Nutno dodat, že výše zmíněné postupy byly zejména konzervativními vrstvami muslimské společnosti interpretovány jako „rudý teror“ režimu namířený vůči celé muslimské komunitě v etno-konfesním smyslu.

I přes represivní charakter režimu byla zaručena jistá míra náboženské svobody. Pravoslavná církev i muslimská náboženská obec mohly i po válce působit, byly ovšem podrobeny dohledu státu, a některé osoby, specificky členové strany a státní zaměstnanci, nemohly svou víru deklarovat veřejně. ${ }^{114} \mathrm{Na}$ začátku padesátých let probíhala akce skidanje zara i feredže (sundávání závojů a šátků), prováděná zprvu dobrovolně a posléze povinně jako cesta k emancipaci socialistické ženy. ${ }^{115}$ Co se týče nábožensky motivované opozice, i ze Sandžaku přicházely pro režim znepokojivé zprávy o působení ilegální organizace Mladi muslimani. ${ }^{116}$ Obecně lze však konstatovat, že v Sandžaku, ostatně tak jako v Bosně, došlo po válce $\mathrm{k}$ rychlé nivelizaci sociálních bariér mezi jednotlivými konfesními komunitami, což lze doložit mimo jiné rostoucím počtem smíšených manželství. ${ }^{117}$

Z hlediska hospodářského připomínal a dodnes připomíná Sandžak Kosovo či obdobné periferní oblasti SFRJ. V celojugoslávské perspektivě se tedy jednalo o ekonomicky zaostalý region s podstatně nižší životní úrovní, než jaká byla běžná ve velkých centrech typu Bělehrad či Titograd nebo i ve vyspělejších rurálních oblastech jako Vojvodina. Relativní chudoba byla také hlavním důvodem migrace, a z periferie Sandžaku tak za lepším životem odcházelo nejen muslimské obyvatelstvo. Odliv obyvatel však způsobovaly i nemateriální faktory jako kulturní zaostalost, nemožnost vysokoškolského vzdělání a další. ${ }^{118}$ Specificky muslimové pak odcházeli také do Turecka a hlavně do sousední Bosny a Hercegoviny, kam Sandžaklije přitahovaly historické i osobní vazby a nabídka pracovních míst. Jen do Turecka v poválečné době emigrovalo údajně přes 10000 sandžackých

\footnotetext{
112 Jan Rychlík a Miroslav Kouba, Dějiny Makedonie (Praha: NLN, 2003), 214-15.

113 Hadžišehović, Muslimanka u Titovoj Jugoslaviji, 117-18, 144.

114 Ibid., 127.

115 Ibid., 131.

116 Ibid., 163.

117 Hladký, Bosenská otázka, 221-22.

118 Hadžišehović, Muslimanka u TitovojJugoslaviji, 145.
} 
muslimů. ${ }^{119}$ Později se ale směr migrace místních muslimů částečně změnil, nebot krom velkých urbánních center v samotné Jugoslávii odcházeli také do zemí západní Evropy a Severní Ameriky. ${ }^{120}$

V těsně poválečném období nebyla zřejmě v Sandžaku, a to i v porovnání se zatím nepř́li šs „emancipovaným“ bosenským prostředím, specifická muslimská etnická či dokonce národní identita nějak zvlášt rozvinuta či nebyla alespoň veřejně deklarována. Sčítání lidu z roku 1948 v celém užším Srbsku ${ }^{121}$ tak zaznamenalo jen asi 6500 osob, které se deklarovaly jako „nacionálně nezařazení, v Černé Hoře to bylo jen 380, z čehož polovina z nich žila ve městě Bar, tj. mimo samotný Sandžak. ${ }^{122}$ Ostatní obyvatelé Sandžaku se v tomto sčítání vyjádřili jako Srbové či Černohorci, což je dobře vidět na př́ikladu Nového Pazaru, z náboženského hlediska dominantně muslimského, kde dle sčítání v roce 1948 žilo 1085 „národnostně nezařazených“" a více než 10000 Srbů. ${ }^{123} \mathrm{O}$ pět let později, v roce 1953, se ke kategorii „nezařazení Jugoslávci“ jen v užším Srbsku přihlásilo 64000 osob a rovněž byl zaznamenán nárůst příslušníků tureckého etnika, stále ještě jako rezidua osmanské identity. ${ }^{124} \mathrm{~V}$ Novém Pazaru tak bylo sečteno „nezařazených Jugoslávců“ 6000, Turků 4000 a jen něco přes 3000 Srbů. ${ }^{125} \mathrm{~V}$ celé Černé Hoře bylo jen asi 6000 „nezařazených Jugoslávců“, většina zdejších muslimů se tedy stále ještě hlásila k černohorské národnosti. ${ }^{126}$

Sčítání z roku 1961 však zaznamenalo i v Černé Hoře významný nárůst počtu Muslimů, když se přes 30000 osob deklarovalo jako „Muslimové v etnickém smyslu“, v užším Srbsku pak již 84 000.127 Údaje z roku 1971 hovoří již

119 Džudžević, Sandžak, 49-50.

120 Rastoder, Bošnjaci/Muslimani Crne Gore, 210.

${ }^{121}$ Počty slovanských muslimů v užším Srbsku, tedy Srbsku bez kosovské a vojvodinské autonomie, v zásadě korespondují s jejich počtem v samotném Sandžaku, nebot mimo malých komunit v Bělehradě, Niši, Sabci, Malém Zvorniku a Loznici netvoří slovanští muslimové v užším Srbsku žádné významnější osídlení. Slovanská muslimská populace v Černé Hoře je rovněž, s výjimkou významnější komunity v přímořských okresech Bar a Ulcinj a ve větších urbánních centrech Podgorica a Nikšić, koncentrována v zásadě jen v samotném Sandžaku.

122 „Stanovništvo po narodnosti po popisu od 15. marta 1948. godine“, oficiální stránka Statistického úřadu Republiky srbské, http://pod2.stat.gov.rs/ObjavljenePublikacije/G1948/Pdf/G19484001 .pdf.

123 Ibid.

124 „Stanovništvo po narodnosti po popisu od 1953. godine“, oficiální stránka Statistického úřadu Republiky srbské, http://pod2.stat.gov.rs/ObjavljenePublikacije/G1953/Pdf/G19534001.pdf.

125 Ibid.

126 Ibid.

127 Nacionalni sastav stanovništva SFR Jugoslavije, sv. I (Beograd: Savezni zavod za statistiku, 1981), nestránkováno, http://pod2.stat.gov.rs/ObjavljenePublikacije/G1981/Pdf/G19814001.pdf. 
o 70000 „Muslimů ve smyslu národnosti“ v Černé Hoře a o 125000 v Srbsku. 128 O deset let později, roku 1981, bylo při sčítání lidu zaevidováno v srbské části Sandžaku skoro 150000 a v Černé Hoře 78000 osob, které optovaly pro kategorii „Muslimové jako národ“. ${ }^{129} \mathrm{Z}$ výše uvedeného lze tedy vypozorovat, že rozvoj muslimské nacionální identity byl v Sandžaku jakožto periferii jihoslovanského muslimského osídlení v porovnání s „mateřskou“ Bosnou a Hercegovinou poněkud opožděn. ${ }^{130}$ Periferní vztah v tomto smyslu platil i pro národnostně méně diferencované prostředí muslimů černohorského Sandžaku vůči jeho srbské části.

\section{Závěr}

V Sandžaku, po okupaci Bosny a Hercegoviny nejsevernější výspě Osmanské říše, se demografickými procesy majícími původ minimálně na počátku 19. století postupně vytvořila početná slovanská muslimská komunita. Ta si zejména ve střetu s mladými křestanskými státy a národy již uvědomovala svoje problematické postavení na teritoriu, kde se nacionalismus postupně stával nejvlivnější intelektuální koncepcí. Vyhánění „mohamedánů“ ze severněji položených oblastí Balkánu, kteří ve vlnách přicházeli i do Sandžaku, spolu s místními interkonfesními konflikty významně přispělo k zakoušení jinakosti místních muslimů Sandžaklijů. Ještě na počátku druhé poloviny 20. století lze však jen stěží o těchto muslimech hovořit jako o moderním národu či jeho součásti, nebot určující pro jejich vlastní percepci byla premoderní identita muslimsko-osmanská, přičemž i příslušníci ostatních nově se utvářejících národních společenství v regionu na ně zpravidla hleděli jako na pouhé „poturčence“.

V rámci osmanského feudálního systému zůstali sandžačtí muslimové prakticky až do Velké války politicky, sociálně a ekonomickou privilegovanou skupinou, jejíž elity těžily z podřízeného postavení křestanské ráji v regionu. $V$ tomto smyslu měl poněkud zjednodušeně pocitovaný vztah vykořistovatelů a vykořistovaných samozřejmě své konsekvence i pro kvalitu zdejších interkonfesních vztahů. Na revoluční myšlenky moderních nacionalismů rodících se křestanských států a národů i na nesmělé pokusy centra o změnu zavedených pořádků

128 Ibid.

129 Ibid.

${ }^{130}$ Při porovnávání počtu sandžackých Muslimů v rámci po sobě jdoucích sčítání lidu je samozřejmě nutné brát v úvahu mimo jiné také otázku porodnosti. Zejména nárůst počtu Muslimů mezi lety 1971 a 1981 byl primárně zapř́činěn přirozeným přírůstkem populace a nikoli afirmací jejich nacionální identity. 
směrem k možné emancipaci nemuslimů zpravidla reagovaly místní muslimské elity, v závislosti na aktuální politice Cařihradu, bud' př́íklonem k loajalistické politice, nebo reakčně-konzervativním odporem vůči jakýmkoli novotám ohrožujícím jejich výsady. To nevyhnutelně vedlo $\mathrm{k}$ dalším konfliktům mezi oběma komunitami, které vygradovaly $\mathrm{v}$ balkánských válkách a následně obou světových konfliktech.

Nejen na Balkáně byl vztah menšiny a většiny v národním státě zpravidla vztahem poddanství a dominance. Slovanští muslimové v Sandžaku, již byli po balkánských válkách a první světové válce inkorporovaní do jihoslovanského státu, kterému dominoval nacionalismus křestanských národů či jednoho národa o třech větvích, se tak na první pohled poněkud paradoxně ocitli v nezáviděníhodném postavení víceméně trpěné minority „poturčencư“. Ztráta tradičních sociálních, politických a ekonomických privilegií, zejména pozemková reforma provázená pravoslavnou kolonizací, spolu s válečnou zkušeností vedla mnohé Sandžaklije k tomu, že považovali Srby a Černohorce především za dobyvatele a ,jejich“ stát, královskou Jugoslávii, za okupační mocnost. Pro mnoho muslimů se stala řešením emigrace, pro některé ozbrojený odpor. Většina muslimské elity se však nakonec snažila nalézt $s$ režimem $v$ Bělehradě nějaký modus vivendi tak, aby zachovala svébytnost vlastní komunity pojímané stále ještě především v konfesním smyslu a v neposlední ŕadě alespoň část svých starých privilegií.

Rozdíly ve vnímání „společného“ státu jeho jednotlivými národy jasně vynikly již na počátku druhé světové války. Jak se záhy ukázalo, většina nejen sandžackých muslimů neměla královskou Jugoslávii za "přirozenou domovinu“ či státní útvar, se kterým by ve státoprávním smyslu spojovala svou budoucnost, což bylo v př́mém rozporu s národní percepcí srbskou. Ostatně srbská nacionalistická politika, jejímiž nejviditelnějšími představiteli se za války stali četnici, považovala „poturčence“ nejen za odrodilý element neslučitelný s ideou srbství, ale i za nehodné toho, aby vůbec obývali prostor budoucího velkého Srbska/ Jugoslávie. Muslimská politika ve strategicky významném Sandžaku, rozkládajícím se mezi bosenskými, západosrbskými a černohorskými bojišti, přitom oscilovala mezi kolaborací, domobranou a spoluprací s Titovými partyzány.

Budování moderního národa Muslimů/Bosňáků bylo až do druhé světové války, a v Sandžaku ještě o něco déle, $v$ zásadě jen prací úzké intelektuální vrstvy národních buditelů. Teprve až v socialistické Jugoslávii byly vytvořeny př́hodné politické a socioekonomické podmínky i institucionální předpoklady pro masový rozvoj národní identity jihoslovanských muslimů. Nová Jugoslávie jako federace založená na - v př́padě Muslimů postupné - afirmaci nacionálních identit tak v rámci oficiální politiky „bratrství a jednoty“ poskytla stále ještě spíše 
etno-konfesně definovanému muslimskému obyvatelstvu do té doby nebývalý prostor pro nacionální emancipaci. Po válce v Sandžaku také postupně došlo k významnému zlepšení zjitřených interetnických vztahů spojenému s nivelizací kulturních a sociálních bariér mezi muslimy a pravoslavnými v dynamickém procesu socialistické modernizace.

Identita sandžackých muslimů byla ovšem ještě dlouho po druhé světové válce primárně konstruována jako konfesní a lokální, v zásadě neoosmanská, byt' v pocitované jinakosti v kontaktu se Srby či Černohorci. Do periferního Sandžaku a k místním muslimům pronikaly ideje nacionální emancipace především ze Sarajeva, které se stalo přirozeným centrem muslimského národního života v Jugoslávii. Od prvního poválečného cenzu, kdy se většina muslimů v Sandžaku přihlásila k srbské či černohorské národnosti, tak postupně v průběhu padesátých, šedesátých a sedmdesátých let došlo i zde k masové afirmaci nacionální identity Muslimů. Zprvu poměrně rezervovaný vztah Sandžaklijů k nové dominantně křestanské Jugoslávii s ateistickým režimem se také postupně proměnil. Jugoslávie se tak stala, byt jen na poměrně krátkou dobu, „přirozeným domovem“ sjednocujícím většinu slovanských muslimů na Balkáně. 